\title{
ANTIULCEROGENIC AND MUCOGENIC ACTIVITY OF XYLOPIA AETHIOPICA FRUIT EXTRACT IN RAT
}

\author{
O. O. OKWARI, R. O. NNELI AND E. E. OSIM \\ (Received 9 October 2012; Revision Accepted 8 January 2013)
}

\begin{abstract}
Prolong administration of non steroidal anti-inflammatory drugs, alcohol, irritants and stress can cause peptic ulcer. In the present investigation, the effect of indomethacin, alcohol and hypothermia induced stress on Xylopia aethiopicafed rats was studied. Peptic ulcers were induced by oral administration of indomethacin $(50 \mathrm{mg} / \mathrm{kg})$ or alcohol $(10 \mathrm{ml} / \mathrm{kg})$ or 2-hour exposure to cold $\left(15-20^{\circ} \mathrm{C}\right)$. The animals were anaesthetized, their abdomens opened and stomachs removed for macroscopic assessment of ulcers, and mucus secretion. The fruit extract of Xylopia aethiopica reduced the induced gastric ulcers caused by indomethacin and increased mucus secretion dose dependently when compared with control. Likewise, the mean gastric ulcer indexes were significantly reduced and mucus secretion increased in the ethanol induced model when compared with control. In the hypothermic stress induced gastric ulcers, the values of the mean ulcers were also reduced significantly, but mucus secretion was only significantly higher in the high dose extract-treated group than in control. These results show that consumption of the fruit of xylopia aethiopica could reduce incidence of peptic ulcer. The increased secretion of mucus in the test animals suggests that prostaglandins might have been produced since they are known to stimulate mucus secretion. It is concluded that the fruit extract of Xylopia aethiopica stimulated mucus secretion and reduced peptic ulceration in the rat.
\end{abstract}

KEYWORDS: Xylopia aethiopica, ulcer, indomethacin, alcohol, stress.

\section{INTRODUCTION}

Xylopia aethiopica fruit contains several phytoconstituents among which are flavonoids, polyphenols, vitamins $\mathrm{A}, \mathrm{C}$ and beta carotene (Okwari 2011). Most people in the Eastern and Western parts of Nigeria use this fruit as spices, soup flavor and for special dishes. Others use it for its medicinal properties since it is believed to cure dysentery, bulimia (Burkhill, 1985; Abbiw, 1990). It is possible that some tradition physicians use it to treat stomach upset? If this is the case, some of stomach upset may be attributed to peptic ulcer.

Peptic ulcer is prevalent among Africans (Enyikwola,1994). In Nigeria, there are reports that its frequency is highest among the low income group than their counterparts in Europe (Osim et al 1991). Some authors even observed that ingestion of local herbs and irritants aggravate or provoke peptic ulcer (Osim et al, 1991; Enyikwola 1994). Peptic ulcer in most cases is caused by illness, stress, malnutrition, prolong ingestion of non steroidal anti inflammatory drugs (Nash et al 1994, Basil and Haward, 1995). The origin and development of gastrointestinal ulcers are influenced by many factors such as secretion of pepsin, hydrochloric acid, secretion of mucus, blood flow, mucosa barrier, cellular regeneration and endogenous protective agents, epidermal growth factors and prostaglandins (Brzozowski et al, 1999). However, the manner this commonly consumed fruit affects gastric ulcers has not been known. Therefore, since secretion of mucus and hydrochloric acid are among several factors that determine gastric mucosa integrity, in this study, we have investigated the cytopprotective effect of this commonly consumed local spicy fruit, Xylopia aethiopica (Negro pepper) in rat using three models of induced peptic ulcer.

\section{MATERIALS AND METHODS}

\section{$2.1 \quad$ Animals}

A colony of albino Wistar rats kept in the Department Physiology Animal House, College of Medical Sciences, University of Calabar, Nigeria, were obtained and used in this study after due permission from the College of Medical Sciences Ethical Committee. The animals were housed in plastic cages under regular condition of humidity $(45 \pm 5 \%)$, temperature $(28 \pm 2 \%)$, and $12 \mathrm{~h}$ light/dark cycle. The animals were divided into four groups of 6 rats each and given food and water $a d$ libitum.

\subsection{Extraction of adherent mucus}

The extraction of mucus was done by the method described by Ettarh and Okwari, (1999). The rats were fasted overnight and after administration of anesthesia, their abdomens were opened and the stomachs cut and washed in saline and opened along the greater curvature and slightly stretched and supported with dissecting pins on a corkboard. The accumulated mucus was removed using a blunt scalpel into a pre-weighed beaker holding $4 \mathrm{ml}$ of water $(\mathrm{M})$. The final weight of the beaker plus the mucus $(\mathrm{N})$ minus $\mathrm{M}$ gives the weight of the mucus $(Z)$ for each animal in all the groups, i.e. $(\mathrm{N}-$

O. O. Okwari, Department of Physiology, College of Medical Sciences, University of Calabar, Calabar, Nigeria.

R. O. Nneli, Department of Physiology, College of Health Sciences, Abia State University, Uturu, Nigeria.

E. E. Osim, Department of Physiology, College of Medical Sciences, University of Calabar, Calabar, Nigeria. 
$M=Z \mathrm{~g}$ ). This procedure precedes the assessment of ulcer lesions quantification macroscopically.

\subsection{Ethanol Induced Peptic Ulcer}

In the ethanol induced ulcer preparation, rats were starved of food but not water for 18 hours. The control group received saline $(0.9 \% \mathrm{NaCl}) 10 \mathrm{ml} / \mathrm{kg}$ body weight. The low dose (LD) Xylopia aethiopica extract treated group received $100 \mathrm{mg} / \mathrm{kg}$ and the high dose(HD) Xylopia aethiopica extract treated group received $200 \mathrm{mg} / \mathrm{kg}$ and the standard control received cimetidine $50 \mathrm{mg} / \mathrm{kg}, 30$ minutes before oral administration of acid alcohol, $10 \mathrm{ml} / \mathrm{kg}(150 \mathrm{mmol} \mathrm{HCl}$ in $60 \%$ alcohol) (Takeuchi et al 2001). One hour after administration the animals were sacrificed and the abdomens were opened. After washing the stomachs with saline solution in other to remove gastric content and blood clots, the numbers of ulcers were noted. Generally, the ulcers were longitudinal and shallow allowing numerical quantification $(\mathrm{mm})$.

\subsection{Indomethacin Induced Gastric Lesion}

This study followed the method described by Nneli and Woyike, 2008. Food was withdrawn for $24 \mathrm{~h}$ before the antiulcerogenic studies. The control group received saline $(10 \mathrm{ml} / \mathrm{kg})$ while the extract-treated groups (LD and $\mathrm{HD}$ ) received $100 \mathrm{mg} / \mathrm{kg}$ and $200 \mathrm{mg} / \mathrm{kg}$ of the extract orally, respectively. The standard control received $50 \mathrm{mg} / \mathrm{kg}$ cimetidine (im). Indomethacin $(50 \mathrm{mg} / \mathrm{kg})$ was given orally $1 \mathrm{~h}$ later. All animals were sacrificed by an overdose of diethyl ether/chloroform mixture 4 hour afterwards. The abdomens were cut open and stomachs removed and rinsed in normal saline solution. Ulcer study and mucus estimation followed as previously described. The potency of the extract was expressed in terms of percentage inhibition.

\section{$2.5 \quad$ Stress Induced Ulcers}

Stress ulcers were induced according to the method described by Senay and Levine (1967). The Rats were fasted for $24 \mathrm{hr}$ and 30 minutes before administration of extract or saline or cimetidine and each animal was restrained in a cold chamber $\left(15-20^{\circ} \mathrm{C}\right)$ for $2 \mathrm{~h}$ (Tagaki et al, 1963). The rats were then removed from the restrainer and sacrificed by an overdose of diethyl ether and chloroform and their abdomens were opened and stomachs removed and opened along the greater curvature and examined for gastric lesions. The lengths of the lesions were determined and the potency expressed as a percentage inhibition.

\subsection{Assessment of Ulcer}

The assessment of ulcer was carried out following the methods described by Elegbe (1978). Using an x2 hand lens, the ulcers were scored macroscopically. The ulcers were graded as follows: ulcer score $\mathrm{O}$, normal stomach; ulcer score 0.5 , punctuated haemorhage or pin point ulcer; ulcer score 1.0 two or more haemorhagic ulcers of $1-3 \mathrm{~mm}$ diameter; ulcer score 2.0, ulcer greater than $3 \mathrm{~mm}$ diameter.

\section{Ulcer index:}

After grading the ulcer index was calculated thus:

$$
\text { No of rats } x \text { No of grades }
$$

Total no of rats $\times 100 \%$

The ulcer incidence was calculated from

Ulcer inhibition rate (UIR)

No of rats with ulcers

Total no of rats

The ulcer inhibition rate was measured as a percentage reduction in the mean ulcer area post administration of test substances.

$$
\frac{\text { Ulcer index-ulceration index in test }}{\text { Ulcer ratio index control } x 100 \%}
$$

\section{Statistical Analysis}

Data obtained from the experiment were expressed as mean \pm SEM. Since there were more than two groups ANOV $\bar{A}$ was used and differences between the control and the treatment were tested for significance by student's t-test, $p$-values less than 0.05 were certified significant statistically.

\section{RESULT \\ 3.1 Indomethacin Induced Peptic Ulcer and Mucus Secretion in the Rat}

In the indomethacin model, (Table 1), the values of the mean ulcer index were significantly $(p<0.05)$ lower in test groups compared with control. Similarly, the values of mucus secretion $(\mathrm{g})$ in the test groups were significantly $(p<0.01)$ higher than in control. The inhibitory effect was greater in the high dose group than

\begin{tabular}{|c|c|c|c|c|}
\hline Group & Treatment Dose & $\begin{array}{l}\text { Mean Ulcer } \\
\text { Score }\left(\mathrm{mm}^{2}\right)\end{array}$ & $\%$ Inhibition & $\begin{array}{l}\text { Mucous } \\
\text { Secretion }\end{array}$ \\
\hline Saline Control & $10 \mathrm{ml} / \mathrm{kg}$ & $34.00 \pm 0.76$ & - & $13.0 \pm 0.10$ \\
\hline Cimetidine & $50 \mathrm{mg} / \mathrm{kg}$ & $9.50 \pm 0.50^{* *}$ & 72.06 & $0.18 \pm 0.005^{\star * *}$ \\
\hline Low dose & $100 \mathrm{mg} / \mathrm{kg}$ & $14.50 \pm 0.46^{*}$ & 57.36 & $0.17 \pm 0.01^{* *}$ \\
\hline High dose & $200 \mathrm{mg} / \mathrm{kg}$ & $12.38 \pm 0.78^{*}$ & 63.59 & $0.18 \pm 0.005$ \\
\hline
\end{tabular}
the low dose group (63.59\% and57.36\%) respectively).

Table 1: Results of indomethacin-induced ulcer and mucus secretion the rat. 
3.2 Ethanol-induced peptic ulcer and mucus secretion in the rat

Table 2 shows the effect of Xylopia aethiopica extract on gastric ulcers induced by ethanol. The results showed a significantly $(p<0.001)$ reduced mean values of gastric ulcers index in extract-treated groups than in control. Similarly the mean mucus secretion $(g)$ by the test rats were significantly $(p<0.001)$ higher than in control. The percentage inhibition of the test groups (LD and HD) were $60.13 \%$ and $56.62 \%$ respectively.

Table 2: Results of Ethanol-induced ulcer and mucus secretion in the rat

\begin{tabular}{|c|c|c|c|c|}
\hline Group & Treatment Dose & $\begin{array}{l}\text { Mean Ulcer } \\
\text { Score }\left(\mathrm{mm}^{2}\right)\end{array}$ & \% Inhibition & $\begin{array}{l}\text { Mucous } \\
\text { Secretion }\end{array}$ \\
\hline Saline Control & $10 \mathrm{ml} / \mathrm{kg}$ & $35.74 \pm 0.29$ & - & $14.0 \pm 0.01$ \\
\hline Cimetidine & $50 \mathrm{mg} / \mathrm{kg}$ & $7.38 \pm 0.88^{* *}$ & 79.40 & $0.18 \pm 0.21^{* *}$ \\
\hline Low dose & $100 \mathrm{mg} / \mathrm{kg}$ & $14.50 \pm 0.46^{*}$ & 60.13 & $0.16 \pm 0.08^{* *}$ \\
\hline High dose & $200 \mathrm{mg} / \mathrm{kg}$ & $15.25 \pm 0.59^{\star \star}$ & 56.62 & $0.18 \pm 0.02^{* *}$ \\
\hline
\end{tabular}

3.3 Stress-induced ulcer and mucus secretion in the rat

As shown in Table 3, in the stress model all the test groups significantly $(p<0.001)$ reduced values of mean ulcer index compared with control. The mean mucus levels were significantly higher in the high dose Xylopia aethiopica - treated group than in control. The ulcer inhibition rate was $56 \%$ and $59.26 \%$ for the low and high dose groups respectively, indicating a slight inhibition with insignificant mucus secretion in the low dose group.

Table 3: Stress-induced ulcer and mucus secretion in the rat.

\begin{tabular}{lllll}
\hline Group & Treatment Dose & $\begin{array}{l}\text { Mean Ulcer } \\
\text { Score }\left(\mathrm{mm}^{2}\right)\end{array}$ & \% Inhibition & $\begin{array}{l}\text { Mucous } \\
\text { Secretion }\end{array}$ \\
\hline Saline Control & $10 \mathrm{ml} / \mathrm{kg}$ & $37.15 \pm 0.67$ & - & $0.11 \pm 0.01$ \\
Cimetidine & $50 \mathrm{mg} / \mathrm{kg}$ & $9.88 \pm 1.03^{* * *}$ & 73.83 & $0.14 \pm 0.01^{* *}$ \\
Low dose & $100 \mathrm{mg} / \mathrm{kg}$ & $16.63 \pm 0.29^{* * *}$ & 55.95 & $0.13 \pm 0.01^{\mathrm{Ns}}$ \\
High dose & $200 \mathrm{mg} / \mathrm{kg}$ & $15.38 \pm 0.92^{* * *}$ & 59.26 & $0.13 \pm 0.004^{* * *}$ \\
\hline
\end{tabular}

${ }^{\star *}=P<0.01{ }^{* \star *}=P<0.001$ vs Control values in mean \pm SEM, $n=6$. NS = not statistically significant.

\section{DISCUSSION}

The aqueous extract of Xylopia aethiopica fruit inhibited the development of indomethacin, alcohol and hypothermic induced ulcers in the rat. Xylopia aethiopica has been shown to contain poly-unsaturated fatty acid (Barminas et al, 1999), which are necessary for the synthesis of prostaglandins. Prostaglandins are known to protect gastric mucosa from auto digestion (Miller, 1983). Derivatives of prostaglandins whether endogenous or exogenous are known to act on multiple receptors (Coleman et al, 1994) to offer cytoprotection mediated by EP1 receptor (Araki et al, 2000)

Indomethacin, a potent cyclooxygenase (COX) inhibitor, causes gastric ulcers which the extract inhibited. Prostaglandins are produced by the activity of iso-forms of COX (COX-1, COX-2) and they are known to play important role in the mechanism of gastric mucosa integrity, gastro protection, and ulcer healing (Hiriata et al, 1998; Konturek et al, 1998; Brzozowski et al, 2000). Mucus secretion was increased following treatment with Xylopia aethiopica. These suggest that the extract may be acting through a prostaglandin dependent pathway since prostaglandins cause mucus secretion (Engel - Guth et al, 1995).

In the acid alcohol induced model, the direct cytoprotective property of the extract was assessed, though not depending on the gastric juice. The extract protective activity showed that the effect may partly be by acid inhibiting action, since profuse acid secretion remains the major cause of peptic ulcer (Glavin and Szabo, 1993). The protective role of mucus against acid and pepsin has been attributed to the gel forming properties which prevents back flow of hydrogen ions (Allen et al, 1993; Terrano et al, 1993). It may also be that Xylopia aethiopica contains phytoconstituents which inhibited ulcers like terpenes (Matsunagu et al, 2001; Hurima-Linda et al, 2001); flavonoids (Reyes et al, 1996, Alzerez et al, 1997); vitamin A, C and beta carotene (Okwari, 2011) which are known antioxidants. The significant impact on the secretion of mucus suggests that the bicarbonate ion may be secreted also by the stomach. Muco-bicarbonate layer formed by the continuous secretion of mucus and bicarbonate in response to acid is one of the many mechanisms responsible for cytoprotection (Engel- Guth et al, 1995). 
Xylopia aethiopica also protected the gastric mucosa against hypothermic induced stress ulcers. It is known that ambient temperature has direct and indirect effect in the rat (Mercer, 1998). Direct effects are mediated by physical disruption of organelles with the cells, high incidence of salt and free radicals. The indirect effects depend on the rate and duration of drop in temperature (Bellester and Harchelroad, 1999; Hanania and Zimmerman, 1999). Reactive oxygen species have been reported to be important mediators of stress in many cell types (Adler et al, 1999; Benhard et al, 2001). Antioxidants are known to block the initiation of free radical formation or inactivate and/or terminate their free radical damage (Salvemini and Cuzzocrea, 2002). Xylopia aethiopica contains (flavonoids, beta carotene, vitamins $A, C$ ) antioxidants that may have reduced free radical activity in the rat in this study.

Prostaglandin synthesis, mucus secretions are among other factors intimately involved in adaptive cytoprotection against mild irritants (Terrano et al, 1993). Takeuchi et al, (2001) demonstrated that endogenously or exogenously derived prostaglandins (PGE2) protective role is mediated by the activation of EP1 receptor. It may be that the action of Xylopia aethiopica may be mediated by activation of EP1 receptor subtype in the gastric mucosa, though this need further experiments. In conclusion, Xylopia aethiopica stimulated mucus secretion and reduced incidence of ulcer formation in the rat. If these results are applicable to humans, Xylopia aethiopica may be beneficial for those suffering from peptic ulcer disease.

\section{REFERENCES}

Abbiw, P., 1990. Useful plants of Ghana Intermediate Technology. Royal Bot. Guard. Kew 337.

Adler, V., Yin, Z., Tew, K. D and Ronia Z., 1999. Role of Redox potential and reactive oxygen species in stress signaling. Oncogene. 18:6904-6111.

Alzarez, A., Pomar, F., Sevilla, M. A and Montero, M. J., 1997. Gastric antisecretory, anti ulcer activity of an ethanolic extract of Biden Palosal Va Radiata Schult Bip .Journal Ethnopharmacol (b) 333 340.

Allen, A., Flemstron, G and Kwlilaakso, E., 1993. Gastroduodenal protection. Physiol. Rev. (73): 823-827.

Araki, H., Vagi, K., Suzuki, K., Furukawa, $\mathrm{O}$ and Takeuchi, K., 2000. Roles of prostaglandin E receptor subtypes in cytoprotective action of prostaglandin E2 in rat. Aliment. Pharmacol. Ther. 14 (Suppl): 18-25.

Barminas, J. T., James, M. K and Abubaka, U. M., 1999. Chemical composition of seed and oil of Xylopia aethopica growth in Nigeria. Plant Food. HUM. Nutr. 53, (3): 193-198.
Basil, M. D and Haward, M. S., 1995. Clinical Gastroenterology. In: Companion Handbook $4^{\text {th }}$ Edition USA McGrew Hill.

Bellester, J. M and Harchelroad, F. P., 1999. Hypothermia: An Easy to miss dangerous disorder in winter weather. Geriatrics 54, (2): 5157.

Benhard, M., Dalyot, I., Engelberg, D and Leviitzki, A., 2001. Enhanced ROS production in oncogenically transformed cells potential C-JUN N-termal Kinase and P-38 mutagen activates protein activity and sensitization of genetoxic stress. Mole Cell Biol ZI: 6913-6926.

Brzozowski, T., Konturek, P. C. H and Konturek, S. J., 2000. Gastroprotective and ulcer healing effect of nitric oxide-releasing NSAID. Digest. Liver Disease: (32): 583-594.

Brzozowski, T., Konturek, P. C. H and Konturek, S. J., 1999. The role of prostaglandin generated by cylooxygenese -1 and cyclooxygenase- 2 in healing of ischemic - reperfusion in rat. European J. Pharmacology (385): 47-b.

Burkhill, H. M., 1985. Useful plants of West Tropical Africa. A Revision of Dalziel (ed) p. 29.

Coleman, R. A., Smith, W. L and Narumiya, S., 1994. Classification of prostanoid receptors, properties, distribution and structure of receptors and their subtypes. Pharmaco. Rev. (46): 205-229.

Elegbe, R. A., 1978. Comparative study on starvation and indomethacin induced in rats. Biochem. Exp. Biol 16 159-166.

Engel-Guth, P. H., Nishizaki, Y and Kaunitz, J. D., 1995. Barrier Function of gastric mucosa gel. American J. physiology. (264): G994-G999.

Enyikwola, O., 1994. Effect of Guinea Pepper (Aframomum melegueta) on Gastric Acid secretion in Albino Rats. Int. J pharmacognosy L pp 37-43.

Ettarh, R. R and Okwari, O. O., 1999. Some Pharmacological studies of the aqueous extract of Dombeya buttneri in the rat PGD-P Thesis Department of Physiology, FBMS University of Calabar Nigeria.

Glavin, G. B and Szabo, S., 1993. Experimental gastric mucosa injury. Laboratory model reveals mechanisms of pathogenesis and new therapeutic strategies. Fed. Am. Soc. Biol. J. (6): 825-833.

Hanania, N. A and Zimmerman, J. L., 1999. Accidental hypothermia. Critical Care Clinic 15235 - 249. 
Hirata, T., Ukawa, H., Yamakuni, Kato, S and Takeuchi, K., 1998. Cyclooxygenase iso enzymes in acute mucosal alcerogenic and functional responses following barrier disruption in rat. British $\mathrm{J}$. pharmacology 122, 447-474.

Hiruma-Linda, C. A., Gracioso, J. S., Toma, W., Almeida, A. B., Paul, A. C. B and Basil, D. S. B., 2001. Grastro protective effect of asparisthman, a diterpene isolated from Asparisthmum of cordatum on experimental gastric ulcer models in rat and mice phytomedicine (8): $94-100$.

Kishimoto, Y., Wada, K and Nakamoto, J., 1998. Quantitative analysis of cyclooxygenase-2 gene expression on acute gastric injury induced by ischemic reperfusion in rat. Life Science: 60, 127-133.

Konturek, P. C., Brzozowski, S. J., Tank, A., Kwieciens, S., Pajdo, R., Sliwowski, Z and Hahn, E. G., 1998. Bacterial lip polysaccharide protects gastric mucosa against gastric injury in rat by activation of genes for cycloozigenase and endogenous prostaglandins. Digestion 59, (29): 284-297.

Matsunaga, T., Hasegawa, C., Kawasuji, T., Suzuki, H and Sagio, K. H., 2000. Isolation of antiulcer compound in essential oil from the leaf of crytomeria japonica. Bio Pharm Bull 23595 - 598.

Mercer, J, B., 1998. Hypothermic and cold injuries in man. In: Blattes. CM (ed) Physiology and Pathophysiology of Temperature Regulation pp. 240 - 256. World Scientific publication. River Edge.

Miller, T. A., 1983. Protective effects of prostaglandin against gastric mucosa damage: current knowledge and proposed mechanisms AM. J. Physiol. 245, g601-G623.

Nash, J., Lynn, L and Deakin, M., 1994. Histamine $\mathrm{H}_{2}-$ recceptor agonist in prophylactic use. Drug. (47): 862-871.
Nneli, R, O and Woyike, O. A., 2008. Antiulcerogenic effect of Coconut (Cocos nucifera). Phytother. Res. (22): 970-972.

Okwari, O. O., 2011. Effect of aqueous extract of Xylopia aethiopica (Nigro pepper) on gastrointestinal function in rat. Ph. D Thesis. College of Medicine and Health Sciences. ABSU. Nigeria.

Osim, E. E., Arthur, S. K and Etta, K. M., 1991. Influence of kola nuts (cola nitida alba in vivo secretion of gastric Acid in Cats. International J. Pharmacognosy 3, 215-220.

Reyes, M., Martin, C., Alarcon de la Lastr, C., Trujillo, J., Toro, M. V and Ayuso, M. J., 1996. Antiulcerogenicity of the flavonoid fraction of Erica andevalensis cabezudo-river Z. Nat urforsch (C) 51, 563-569.

Salvemini, D and Cuzzocrea, S., 2002. Supper peroxide, Supper peroxide dismutase and ischemic injury. Current Opinion on Investigation of drugs. 3, 886.

Senay, E. C and Levine, J. R., 1967. Synergism between cold restrain and rapid restrain ulcer in rat. Proc Soc Exper. Biol 124, 1221-1223.

Tagaki, T., Kasuya, Y and Wanake, K., 1963 studies in drugs for peptic ulcer. A reliable method for producing stress ulcer in rat. Chem. Pharm. Bull. (12): 456-472.

Takeuchi, K., Araki, H., Umeda, M., Komoike, Y and

Suzuki, K., 2001. Adaptive Gastric cytoprotection is mediated by prostaglandin EPI Receptors: A study using rats and knockout mice. Pharmacology and Experimental Therapeutics 297, (3): 1160-1165.

Terrano, A., Ota, S., Hiraish, H and Mutoh, H., 1993. Gastric Cytoprotection: Morphological perspective. Acta Pathologic, Japan. (43): 2-10. 